\title{
PRODUK ENKAPSULASI ASAP CAIR SEKAM PADI DAN APLIKASINYA UNTUK MENGAWETKAN TAHU PUTIH
}

Liquid Smoke Encapsulation Product and Its Applications to Preserve The White Tofu

\author{
Ana Andiana ${ }^{1)}$, Nur Aini ${ }^{1) *}$, Karseno Karseno ${ }^{1)}$ \\ ${ }^{1)}$ Program Studi Teknologi Pangan, Fakultas Pertanian, Universitas Jenderal Soedirman \\ Jalan Dr. Soeparno No. 73, Purwokerto, 53122 \\ *Korespondensi Penulis: nur.aini@unsoed.ac.id
}

\begin{abstract}
Tofu is a perishable food product, thus requiring a safe natural preservative. Liquid smoke from rice husk can be used as a tofu preservative, but its use in liquid form is less practical. Liquid smoke encapsulation process is a way to resolve the issue. The research objectives were to study the antibacterial activity of liquid smoke from rice husks and their encapsulated products, the effect of the concentration of liquid smoke encapsulation products on the shelf life of white tofu during storage, and the optimal concentration of liquid smoke encapsulation products that were able to maintain the quality of white tofu during storage. This type of research was experimental using a Split Plot Design, with the main plot was the concentration of encapsulated products, while the sub-plot was the storage time. Factors studied were the storage time (0,2, 4 and 6 days) and encapsulation product concentrations $(0,0.5,1,1.5$ and $2 \%)$. There were 20 combinations of treatment, repeated two times in order to get 40 units of trial. The results showed that the liquid smoke of rice husk had total phenol of 1,624.62 mg GAE/g, also had antibacterial activity against Escherichia coli ATCC and Staphylococcus aureus ATCC. Encapsulation product of rice husk liquid smoke had total phenol of 3,125 $\mathrm{mg} \mathrm{GAE} / \mathrm{g}$ and antibacterial activity against Escherichia coli ATCC and Staphylococcus aureus ATCC. The concentration of the encapsulated product affected the value of water content, protein content and the total plate count (TPC) during storage. The concentration of $2 \%$ encapsulated product produced the lowest changes during storage. The concentration of $1 \%$ encapsulated product resulted in tofu quality that was still organoleptically feasible until the second day of storage.
\end{abstract}

Keywords: encapsulation, liquid smoke, white tofu

\section{PENDAHULUAN}

Tahu merupakan salah satu makanan yang digemari oleh hampir semua kalangan masyarakat di Indonesia. Konsumsi tahu rata-rata per orang per tahun pada 2018 mencapai 8,32 kg/kapita dan diperkirakan terus meningkat menjadi 8,62 $\mathrm{kg} / \mathrm{kapita}$ pada tahun 2020 (Badan Pusat Statistik, 2019)

Tahu putih merupakan salah satu jenis produk pangan yang mudah mengalami kerusakan. Sebagian pedagang menambahkan pengawet yang tidak boleh digunakan untuk pangan agar tahu memiliki daya simpan yang lama. Salah satu jenis pengawet yang bukan untuk pangan yang disalahgunakan dalam mengawetkan tahu yaitu formalin. Menurut Yuliarti (2007) formalin seharusnya tidak digunakan untuk pangan. Akan tetapi hal tersebut disalahgunakan oleh masyarakat untuk memperbaiki warna dan tekstur pangan serta menghambat aktivitas mikroorganisme sehingga produk pangan dapat disimpan lebih lama. Solusi yang dapat dilakukan adalah dengan menggunakan bahan pengawet alami yang bersifat antibakteri. Salah satu bahan alami yang bersifat antibakteri adalah asap cair.

Asap cair merupakan bahan pengawet alami yang mampu menghambat pertumbuhan bakteri pada makanan karena mengandung senyawa-senyawa fenol, karbonil dan asam. Senyawa tersebut diperoleh dari proses pirolisis (Ginayati et $a l ., 2015)$. Penggunaan dalam bentuk cairan 
dianggap kurang praktis terutama dalam proses distribusi dan transportasi karena memerlukan wadah dan tempat khusus. Menurut Maryam (2015), senyawa fenolik asap cair juga mudah mengalami kerusakan (oksidasi). Oleh karena itu, pengembangan teknologi diperlukan untuk melindungi komponen aktif asap cair serta memudahkan dalam penanganannya yaitu dengan membuat produk enkapsulasi asap cair.

Menurut Wang et al. (2009), enkapsulasi merupakan proses melapisi partikel padatan, droplet cairan, atau gas. Metode yang digunakan adalah spray drying dengan maltrodektrin dan kitosan sebagai media pembawa. Menurut Kurniasih et al. (2016) yang telah melakukan penelitian dengan menggunakan asap cair terenkapsulasi maltodekstrin-kitosan, hasil menunjukkan bahwa pada konsentrasi $1 \%$ dapat menghambat pertumbuhan bakteri pada steak ikan cakalang selama penyimpanan 12 jam pada suhu ruang $\left(30^{\circ} \mathrm{C}\right)$. Sekam padi bisa dijadikan sebagai bahan dalam pembuatan asap cair. Pemilihan sekam padi dikarenakan memiliki ketahanan yang tinggi terhadap penetrasi cairan dan dekomposisi yang disebabkan oleh jamur (Wibowo et al., 2008). Kandungan karbon yang tinggi pada sekam padi mengindikasikan banyaknya kandungan polisakarida (selulosa) sekam (Prabawati et al., 2008). Penelitian asap cair sekam padi sebelumnya telah dilakukan Swastawati (2008) menyatakan bahwa asap cair sekam padi yang diaplikasikan pada ikan lele menyebabkan perubahan karakteristik pada ikan lele asap.

Oleh karena itu, dilakukan pemanfaatan asap cair sekam padi melalui enkapsulasi asap cair dan aplikasinya pada tahu putih sehingga diketahui pengaruhnya terhadap umur simpan tahu yang dihasilkan. Tujuan penelitian ini adalah untuk mempelajari aktivitas antibakteri pada asap cair sekam padi dan produk enkapsulasi asap cair sekam padi, pengaruh konsentrasi produk enkapsulasi asap cair sekam padi terhadap mutu tahu putih (kadar air, kadar protein, total mikroba dan sifat organoleptik) selama penyimpanan dan konsentrasi optimal produk enkapsulasi asap cair sekam padi yang mampu mempertahankan mutu tahu putih selama penyimpanan.

\section{METODE PENELITIAN}

\section{Alat dan Bahan}

Asap cair sekam padi merk La Fronthea dibeli di PT. Asap Cair Multiguna, Universitas Diponegoro, Semarang. Alatalat yang digunakan yaitu alat pembuatan tahu meliputi tungku, wajan, penggilingan, pengpres. Alat utama pengeringan untuk mikroenkapsulasi yaitu spray dryer, oven (Memmert 854 Schwabach, Germany), timbangan analitik (AND), tabung reaksi (Pyrex), sentrifus (Gemm PLC-03), spektrofotometer UV-Vis (shimadzu 1800), erlemeyer (Pyrex), labu ukur (Pyrex), pipet ukur (Pyrex), cawan petri (Pyrex) dan labu Kjeldahl (Iwaki).

Bahan yang digunakan dalam produksi tahu adalah kedelai, biang tahu (whey tahu, yaitu air sisa pembuatan tahu 12 hari sebelumnya) dan asap cair. Bahan untuk enkapsulasi dan analisis adalah maltrodektrin, spiritus, alkohol teknis $70 \%$ (diperoleh dari toko kimia Prima), kitosan (didapat dari CV. Chem-Mix Pratama), bakteri Staphylococcus aureus ATCC dan bakteri Escherichia coli ATCC. Reagen folin ciocalteau, kalium sulfat $\left(\mathrm{K}_{2} \mathrm{SO}_{4}\right)$ dan natrium agar (Merck) yang diperoleh di laboratorium tanah dan laboratorium agronomi.

\section{Tahapan Penelitian}

Proses Produk Enkapsulasi Asap Cair Sekam Padi

Asap cair sekam padi merk La Fronthea dibeli di PT. Asap Cair Multiguna, Universitas Diponegoro. Pembuatan produk enkapsulasi asap cair menggunakan metode Saloko et al. (2012) dengan 
penyalut berupa maltodektrin dan kitosan dengan perbandingan $1,5 \%: 8,5 \%$ serta ditambahkan natrium tripolifosfat 1 $\mathrm{mg} / \mathrm{mL}$. Setelah diperoleh larutan enkapsulasi dilakukan penyemprotan dengan alat spray dryer dengan suhu inlet $150^{\circ} \mathrm{C}$ sehingga diperoleh produk enkaspulasi asap cair sekam padi.

\section{Aplikasi Produk Enkapsulasi Asap Cair Sekam Padi pada Tahu Putih}

Kedelai dicuci lalu direndam air panas kemudian ditiriskan. Kedelai kemudian digiling dengan penambahan air hangat. Bubur kedelai kemudian disaring menggunakan kain saring. Filtrat yang dihasilkan kemudian dimasak sampai mendidih dan ditambahkan biang tahu sedikit demi sedikit sehingga terbentuk gumpalan. Setelah terbentuk gumpalan kemudian disaring, selanjutnya dilakukan pengepresan. Gumpalan tahu yang dihasilkan kemudian ditimbang seberat 100 gram dan ditambahkan produk enkapsulasi asap cair sekam padi sesuai perlakuan, dibiarkan selama 30 menit dan dilakukan pengepresan kembali. Tahu putih yang diperoleh kemudian dilakukan analisis.

\section{Rancangan Percobaan}

Penelitian ini merupakan jenis penelitian eksperimental menggunakan rancangan split plot sebagai rancangan percobaan. Faktor yang diteliti yaitu lama penyimpanann terdiri dari 0 hari, 2 hari, 4 hari, 6 hari; dan konsentrasi produk enkapsulasi asap cair sekam padi dengan konsentrasi $0 \% ; 0,5 \% ; 1 \% ; 1,5 \%$ dan $2 \%$.

Data yang diperoleh, kemudian dianalisis keragaman pada taraf $5 \%$. Apabila terdapat keragaman dilanjutkan dengan uji Duncan Multiple Range Test (DMRT) dengan taraf 5\% untuk analisis produk tahu putih.

\section{Metode Analisis}

Analisis pada asap cair meliputi total fenol (Senter et al., 1989) dan uji antibakteri (Kirby-Bauer). Analisis produk enkapsulasi asap cair meliputi total fenol
(Senter et al., 1989) dan uji antibakteri (Kirby-Bauer).

Produk tahu putih yang dianalisis kadar air (AOAC, 2005); kadar protein (AOAC, 2005), Total Plate Count (TPC) (Fardiaz, 1992), uji mutu hedonik dengan 30 panelis semi terlatih dengan skor 1-5 (Meilgaard et al., 2007). Data hasil uji organoleptik diolah menggunakan analisis Friedman dengan taraf 5\%. Perlakuan terbaik ditentukan dengan uji DMRT dan Friedman.

\section{HASIL DAN PEMBAHASAN}

\section{Karakteristik Kimia Asap Cair dan Produk Enkapsulasi Asap Cair Sekam Padi}

Total Fenol

Komponen utama yang terkandung dalam asap cair yaitu kelompok senyawa organik seperti fenol, karbonil dan asam. Menurut Putra (2010), senyawa fenol bersifat sebagai antioksidan sehingga dapat menghambat kerusakan pangan. Total fenol asap cair dan produk enkapsulasi asap cair sekam padi disajikan pada Tabel 1.

Tabel 1. Total fenol asap cair dan produk enkapsulasi asap cair sekam padi

\begin{tabular}{lcc}
\hline Perlakuan & Asap cair & $\begin{array}{c}\text { Produk } \\
\text { enkapsulasi }\end{array}$ \\
\hline $\begin{array}{l}\text { Total fenol } \\
(\mathrm{mg} \mathrm{GAE} / \mathrm{g})\end{array}$ & $1.624,62$ & 3.125 \\
\hline
\end{tabular}

Total fenol pada asap cair sekam padi sebesar 1.624,62 mg GAE/g (Tabel 1). Kadar fenol asap cair sekam padi yang digunakan lebih rendah dibandingkan dengan kadar fenol pada penelitian oleh Andayani et al. (2014) bahwa asap cair sekam padi sebesar $1.814,0 \mathrm{mg} / \mathrm{L}$. Faktor utama yang menentukan kadar total fenol dalam asap cair adalah banyaknya asap yang dihasilkan selama proses pirolisis berlangsung. Selanjutnya total fenol produk enkapsulasi asap cair sebesar $3.125 \mathrm{mg}$ GAE/g. Kadar fenol produk enkapsulasi asap cair $(0,3 \%)$ lebih rendah dibandingkan 
dengan kadar fenol mikroenkapsulasi tempurung kelapa sebesar 2,08\% (Saloko et al., 2013).

Hasil total fenol asap cair lebih rendah dibandingkan dengan produk enkapsulasi asap cair sekam padi. Hal ini terjadi karena proses enkaspulasinya. Menurut Wang et al. (2009), enkapsulasi dapat melindungi senyawa fenolik yang memiliki aktivitas antioksidan, mencegah kerusakan bahan dari interaksi dengan bahan lain, meningkatkan stabilitas terhadap cahaya dan oksigen.

\section{Antibakteri Asap Cair dan Produk Enkapsulasi Asap Cair Sekam Padi}

Pengujian aktivitas antibakteri asap cair dan produk enkapsulasi asap cair sekam padi dilakukan melalui pengujian daya hambat terhadap bakteri Escherichia coli ATCC mewakili gram negatif dan Staphylococcus aureus ATCC mewakili gram positif. Kontrol positif menggunakan tetrasiklin, karena tetrasiklin aktif terhadap bakteri Gram positif dan gram negatif aerob maupun anaerob (Goodman and Gilman, 2003). Metode pengujian yang digunakan adalah metode Kirby-Bauer, yaitu metode difusi dengan cakram kertas. Konsentrasi yang digunakan pada asap cair yaitu $10 \%$, $50 \%$ dan $100 \%$. Produk enkapsulasi menggunakan konsentrasi $10 \%$ dan $50 \%$, sedangkan konsentrasi $100 \%$ tidak dianalisis dikarenakan produk berupa padatan. Penghambatan asap cair sekam padi dan produk enkapsulasinya terhadap bakteri E. coli ATCC ditandai dengan zona bening (Tabel 2).

Tabel 2. Daya hambat asap cair dan produk enkapsulasi asap cair sekam padi terhadap bakteri Escherichia coli ATCC

\begin{tabular}{ccc}
\hline Perlakuan & \multicolumn{2}{c}{ Zona bening $(\mathrm{mm})$} \\
Asap Cair & $\begin{array}{c}\text { Produk } \\
\text { enkapsulasi }\end{array}$ \\
\hline $10 \%$ & 8,5 & 11 \\
$50 \%$ & 19,8 & 22,5 \\
$100 \%$ & 25,8 & - \\
$\mathrm{K}+$ & 39,1 & 39,1 \\
\hline
\end{tabular}

Keterangan: $\mathrm{K}+=$ kontrol positif (tetrasiklin); - = tidak dilakukan analisis
Konsentrasi asap cair tertinggi (100\%) menghasilkan zona bening sebagai tanda daya hambat E. coli ATCC sebesar $25,8 \mathrm{~mm}$ dan terkecil pada perlakuan $10 \%$ $(8,5 \mathrm{~mm})$. Hal tersebut menunjukkan bahwa semakin tinggi konsentrasi asap cair dan produk enkapsulasinya maka semakin besar zona bening sebagai tanda penghambatan E. coli ATCC (antibakteri). Penghambatan asap cair dan produk enkapsulasi asap cair sekam padi terhadap bakteri $S$. aureus ATCC yang ditandai dengan zona bening pada Tabel 3.

Tabel 3. Daya hambat asap cair dan produk enkapsulasi asap cair sekam padi terhadap bakteri Staphylococcus aureus ATCC

\begin{tabular}{ccc}
\hline Perlakuan & \multicolumn{2}{c}{ Zona bening $(\mathrm{mm})$} \\
Asap cair & $\begin{array}{c}\text { Produk } \\
\text { enkapsulasi }\end{array}$ \\
\hline $10 \%$ & 11,5 & 13,2 \\
$50 \%$ & 22,3 & 24,5 \\
$100 \%$ & 31,1 & - \\
$\mathrm{K}+$ & 45,1 & 45,1 \\
\hline
\end{tabular}

Keterangan: $\mathrm{K}+=$ kontrol positif (tetrasiklin); - = tidak dilakukan analisis

Berdasarkan Tabel 3, terdapat kenaikan daya hambat yang tinggi pada setiap konsentrasi. Hal ini berarti semakin tinggi konsentrasi asap cair dan produk enkapsulasi asap cair sekam padi maka semakin besar zona bening yang dihasilkan terhadap bakteri $S$. aureus ATCC. Hasil pengujian menunjukkan bahwa asap cair dan produk enkapsulasi memiliki aktivitas antibakteri pada $E$. coli ATCC maupun $S$. aureus ATCC dengan terbentuknya zona hambat pada masing-masing konsentrasi. Semakin besar diameter zona hambat maka semakin besar aktivitas antibakterinya (Ningtyas, 2010).

Penggunaan asap cair dan produk enkapsulasi asap cair sekam padi memberikan pengaruh yang berbeda terhadap luas diameter daerah hambatan. Perbedaan ini dikarenakan produk enkapsulasi menggunaan bahan penyalut 
yang dapat membungkus senyawa fenolik dan meningkatkan kemampuan penghambatan. Bahan penyalut yang digunakan pada penelitian ini adalah maltodektrin dan kitosan. Menurut Caliskan and Dirim (2013), meningkatnya konsentrasi padatan terlarut maltodekstrin dapat memperbaiki dan meningkatkan efisiensi dan hasil mikrokapsul ekstrak tanaman sumac (Rhus coriaria L,) serta meningkatkan total fenolik dan antosianin pada tepung ubi ungu. Saloko et al. (2012) juga menyatakan bahwa kitosan sebagai absorber fenol, memiliki sifat pembentuk film, sifat antibakteri dan dapat memperkuat sifat fungsional asap cair sebagai pengawet makanan.

Aplikasi Produk Enkapsulasi Asap Cair Sekam Padi pada Tahu Putih dan Karakteristik Tahu yang Dihasilkan

Tahu putih merupakan produk olahan kedelai yang mengandung protein dan kadar air tinggi sehingga baik untuk pertumbuhan mikroorganisme pembusuk. Hal ini menyebabkan tahu tidak tahan lama dan mudah rusak (Cahyadi, 2008). Oleh karena itu, produk enkapsulasi asap cair sekam padi diaplikasikan pada pembuatan tahu putih. Hasil analisis ragam lama penyimpanan (L), konsentrasi produk enkapsulasi $(\mathrm{K})$ dan interaksi antara keduanya (LxK) pada tahu putih disajikan pada Tabel 4.

Tabel 4. Hasil analisis ragam aplikasi produk enkapsulasi asap cair sekam padi terhadap variabel kimia dan mikrobiologi pada tahu putih

\begin{tabular}{clccc}
\hline No. & Variabel kimia & \multicolumn{3}{c}{ Perlakuan } \\
\cline { 2 - 5 } & dan biologi & $\mathrm{L}$ & $\mathrm{K}$ & $\mathrm{LxK}$ \\
\hline 1. & Kadar air & $*$ & $*$ & $*$ \\
2. & Kadar protein & $*$ & $*$ & tn \\
3. & Total Plate & $*$ & $*$ & tn \\
& Count (TPC) & & & \\
\hline
\end{tabular}

Keterangan: $\mathrm{L}=$ lama penyimpanan; $\mathrm{K}=$ konsentrasi produk enkapsulasi; LxK = interaksi antara lama penyimpanan dengan konsentrasi produk enkapsulasi; $*$ = berpengaruh nyata; tn = tidak berpengaruh nyata pada $\alpha=5 \%$

\section{Kadar Air}

Hasil analisis ragam menunjukkan bahwa lama penyimpanan (L), konsentrasi produk enkapsulasi (K) dan interaksi keduanya (LxK) berpengaruh nyata terhadap kadar air tahu putih. Perubahan nilai rata-rata kadar air tahu putih selama penyimpanan berbagai konsentrasi produk enkapsulasi disajikan pada Gambar 1.

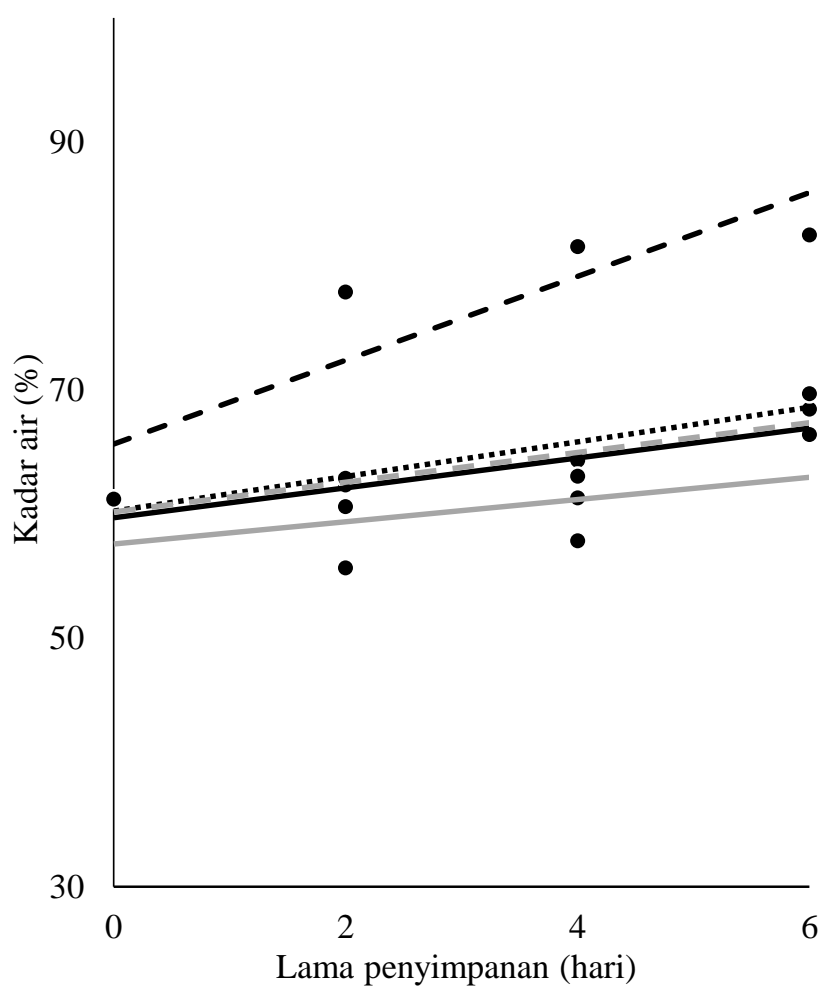

Gambar 1. Perubahan kadar air tahu putih dengan penambahan produk enkapsulasi asap cair selama penyimpanan

Keterangan: $\boldsymbol{=}=\mathrm{K} 0$ (konsentrasi 0\%); m = $\mathrm{K} 1$ (konsentrasi 0,5\%); $=\mathrm{K} 2$ (konsentrasi $1 \%$ ); $\mathbb{E}=\mathrm{K} 3$ (konsentrasi 1,5\%); $=\mathrm{K} 4$ (konsentrasi 2\%)

Gambar 1 menunjukkan bahwa secara keseluruhan kadar air pada tahu putih meningkat selama penyimpanan. Menurut Himawati (2010), peningkatan kadar air bahan disebabkan adanya aktivitas mikroba pada bahan yang akan menghasilkan air selama melakukan proses metabolisme. Nilai slope pada persamaan regresi dijadikan sebagai indikator perubahan variasi perlakuan. Semakin 
tinggi slope maka kemampuan produk enkapsulasi asap cair dalam menghambat peningkatan kadar air makan rendah, begitupun sebaliknya. Konsentrasi 0\% (K0) memiliki kadar air yang paling tinggi dan peningkatan kadar air yang paling tajam memiliki nilai slope 6,7483 dibandingkan penambahan konsentrasi produk enkapsulasi pada konsentrasi 0,5\% $(2,7854) ; 1 \%(2,4154) ; 1,5 \%(2,3896)$ dan $2 \%(1,783)$.

Konsentrasi produk enkapsulasi 2\% menghasilkan kenaikan kadar air paling kecil dibandingkan konsentrari produk enkapsulasi lainnya. Hasil pengamatan tersebut sesuai dengan penelitian Martinez et al. (2007), bahwa kadar air filet salmon asap mengalami peningkatan selama penyimpanan, tetapi masih lebih rendah daripada filet salmon tanpa pengasapan. Selanjutnya analisis DMRT konsentrasi produk enkapsulasi terhadap kadar air tahu putih disajikan pada Gambar 2.

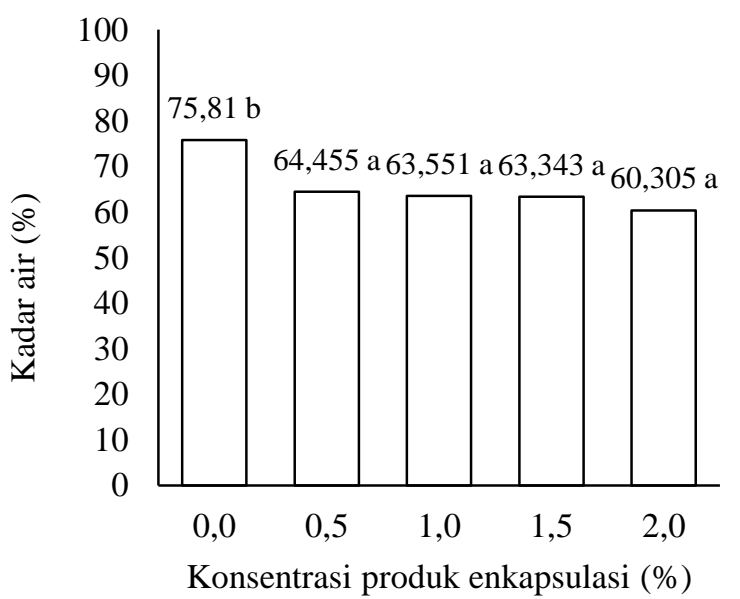

Gambar 2. Kadar air tahu putih berbagai konsentrasi produk enkapsulasi selama penyimpanan

Keterangan: Angka yang diikuti huruf yang sama menunjukkan tidak ada perbedaan nyata pada uji DMRT dengan taraf $\alpha=5 \%$

Gambar 2 menunjukkan bahwa kadar air mengalami perbedaan pada setiap penambahan konsentrasi produk enkapsulasi dikarenakan adanya senyawa fenol. Menurut Setha (2011), penambahan konsentrasi asap cair yang digunakan maka jumlah komponen asap yang melekat pada tahu akan meningkat, sehingga menyebabkan kadar air menurun seiring dengan meningkatnya konsentrasi asap cair. Tahu merupakan bahan pangan dengan kadar air tinggi dan peningkatan kadar air merupakan salah satu indikator penurunan mutu produk. Oleh karena itu pengujian kadar air pada tahu merupakan hal yang penting dilakukan. Hasil penelitian Febriani (2006), bahwa belut asap dengan konsentrasi $10 \%$ lebih tinggi kadar airnya dibandingkan konsentrasi 5\% hal ini dikarenakan adanya senyawa fenol pada asap cair.

\section{Kadar Protein}

Hasil analisis ragam menunjukkan bahwa lama penyimpanan (L) dan konsentrasi produk enkapsulasi (K) berpengaruh nyata terhadap kadar protein tahu putih sedangkan interaksi keduanya (LxK) tidak berpengaruh nyata terhadap kadar protein. Perubahan kadar protein tahu putih selama penyimpanan berbagai konsentrasi produk enkapsulasi disajikan pada Gambar 3.

Secara keseluruhan kadar protein tahu putih menurun selama penyimpanan dikarenakan adanya aktivitas bakteri yang menggunakan nitrogen (Gambar 3). Menurut Amaliyah (2014), bahwa semakin lama penyimpanan jumlah bakteri meningkat sehingga kadar protein menurun. Penurunan dikarenakan banyak bakteri yang memanfaatkan protein sebagai makanannya. Kadar protein tahu putih selama penyimpanan akan menurun, sesuai dengan Rasydta (2013), penurunan kadar protein bandeng presto asap. Penurunan ini karena pertumbuhan mikroorganisme selama penyimpanan semakin meningkat. 


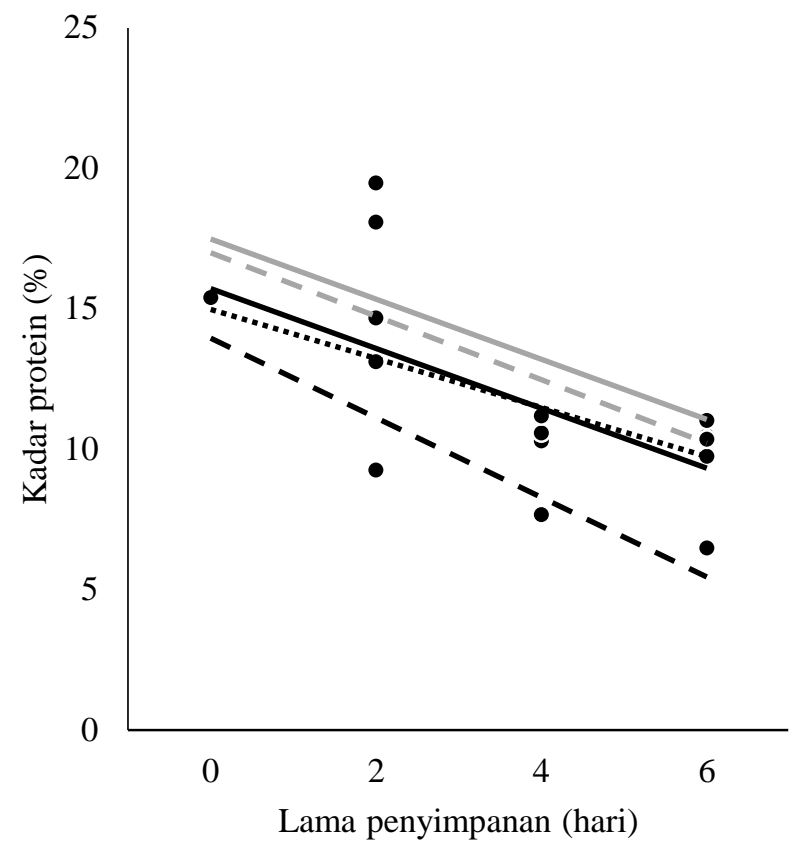

Gambar 2. Perubahan kadar protein tahu putih dengan penambahan produk enkapsulasi asap cair selama penyimpanan

Keterangan: $=\mathbf{=}=\mathrm{K} 0$ (konsentrasi 0\%); ; : : = $\mathrm{K} 1$ (konsentrasi 0,5\%); $=\mathrm{K} 2$ (konsentrasi 1\%); $\square=\mathrm{E}=\mathrm{K} 3$ (konsentrasi 1,5\%); $=\mathrm{K} 4$ (konsentrasi 2\%)

Semakin tinggi nilai slope maka kemampuan produk enkapsulasi asap cair dalam mempertahankan kadar protein semakin rendah, begitupun sebaliknya. Konsentrasi 0\% memiliki kadar protein yang paling rendah dan penurunan protein yang paling tajam dengan nilai slope 2,8332 dibandingkan penambahan produk enkapsulasi dengan konsentrasi $0,5 \%$ ($1,7435) ; 1 \%(-2,1311) ; 1,5 \%(-2,2643)$ dan $2 \% \quad(-2,1393)$. Konsentrasi produk enkapsulasi $2 \%$ menghasilkan penurunan paling kecil dibandingkan konsentrari produk enkapsulasi lainnya. Selanjutnya hasil analisis DMRT konsentrasi produk enkapsulasi terhadap kadar protein tahu putih disajikan pada Gambar 4.

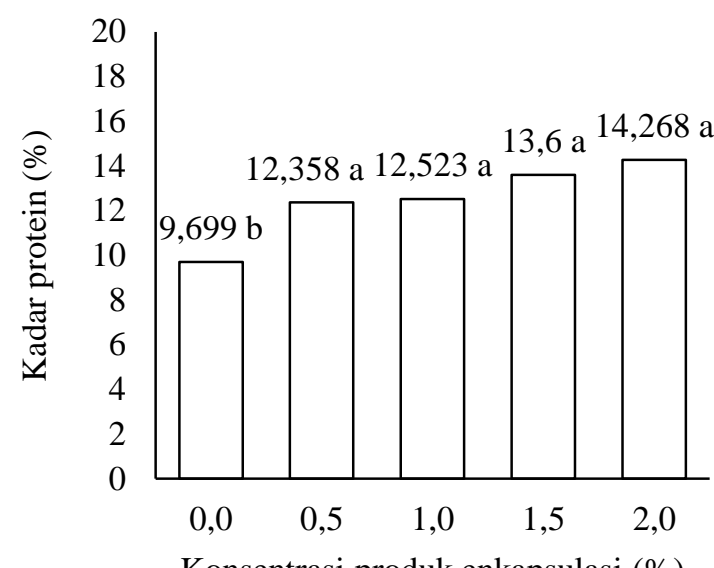

Gambar 4. Kadar protein tahu putih berbagai konsentrasi produk enkapsulasi selama penyimpanan

Keterangan: Angka yang diikuti huruf yang sama menunjukkan tidak ada perbedaan nyata pada uji DMRT dengan taraf $\alpha=5 \%$

Gambar 4 menunjukkan bahwa kadar protein mengalami perbedaan pada penambahan konsentrasi produk enkpasulasi pada tahu putih Menurut Sakti et al. (2016), produk yang mengalami proses pengasapan memiliki kadar protein yang masih tinggi. Tingginya kadar protein pada bahan disebabkan oleh unsur-unsur kimia asap yang melekat seperti senyawa aldehid, asam-asam organik, katon, alkohol, fenol, dan hidrokarbon yang berfungsi sebagai antimikroba, antioksidan, pemberi rasa dan aroma juga dapat berfungsi sebagai pengawet sehingga zatzat protein dalam produk masih kompak.

\section{Total Plate Count (TPC)}

Hasil analisis ragam menunjukkan bahwa lama penyimpanan (L) dan konsentrasi produk enkapsulasi (K) berpengaruh nyata terhadap TPC tahu putih sedangkan interaksi keduanya (LxK) tidak berpengaruh nyata terhadap TPC tahu putih. Perubahan nilai rata-rata TPC tahu putih selama penyimpanan berbagai konsentrasi produk enkapsulasi disajikan pada Gambar 5. 


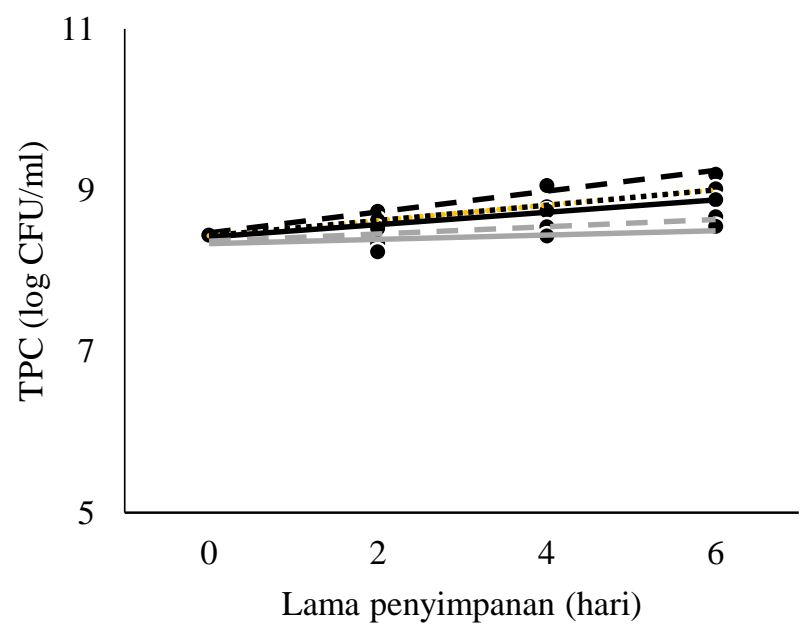

Gambar 3. Perubahan Total Plate Count (TPC) tahu putih dengan penambahan produk enkapsulasi asap cair selama penyimpanan

Keterangan: $\boldsymbol{-}=\mathrm{K} 0$ (konsentrasi 0\%); m = $\mathrm{K} 1$ (konsentrasi 0,5\%); $=\mathrm{K} 2$ (konsentrasi $1 \%) ;-\square=\mathrm{K} 3$ (konsentrasi 1,5\%); $=\mathrm{K} 4$ (konsentrasi 2\%)

Secara keseluruhan TPC (total plate count) pada tahu putih meningkat selama penyimpanan dikarenakan adanya aktivitas bakteri yang menguraikan protein. Tumbuhnya bakteri proteolitik yang menggunakan protein sebagai sumber zat gizinya (Gambar 5). Menurut Ernawati (2012) menyatakan bahwa mikroorganisme memanfaatkan protein untuk melakukan proses metabolisme. Hal tersebut sesuai Soeparno (2005) mengatakan bahwa mikroorganisme dapat menyebabkan kerusakan melalui proteolisis dan penurunan tekstur.

Semakin tinggi nilai slope maka kemampuan produk enkapsulasi asap cair dalam menghambat pertumbuhan bakteri semakin rendah, begitupun sebaliknya. Tahu tanpa diberi produk enkapsulasi pada konsentrasi 0\% (K0) memiliki TPC paling tinggi dan peningkatan yang paling tajam dengan nilai slope 0,2693 dibandingkan penambahan konsentrasi produk enkapsulasi pada konsentrasi 0,5\% $(0,1886) ; 1 \%(0,1535) ; 1,5 \% \quad 0,0898)$ dan $2 \% \quad(0,0531)$. Konsentrasi produk enkapsulasi $2 \%$ menghasilkan penurunan paling rendah dibandingkan konsentrasi produk enkapsulasi lainnya. Selanjutnya hasil analisis DMRT konsentrasi produk enkapsulasi terhadap TPC tahu putih disajikan pada Gambar 6.

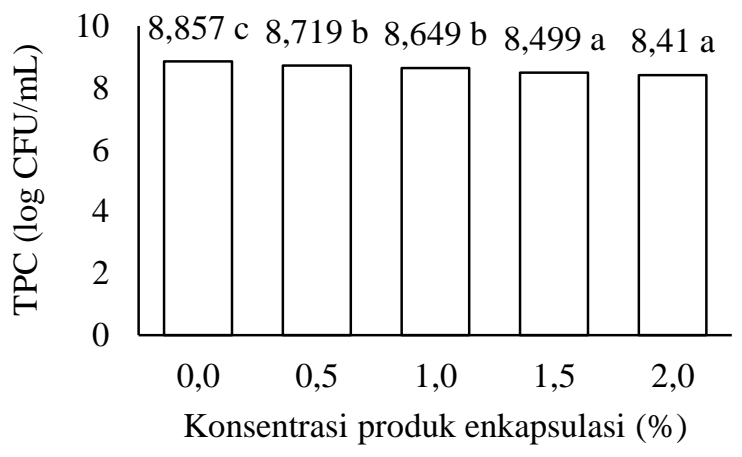

Gambar 6. TPC tahu putih berbagai konsentrasi produk enkapsulasi selama penyimpanan

Keterangan: Angka yang diikuti huruf yang sama menunjukkan tidak ada perbedaan nyata pada uji DMRT dengan taraf $\alpha$ $=5 \%$

Gambar 6 menunjukkan TPC tahu putih mengalami penurunan seiring dengan konsentrasi produk enkapsulasi yang ditambahkan. Penurunan ini dikarenakan produk enkapsulasi memiliki aktivitas antibakteri. Aktivitas antibakteri ini disebabkan oleh senyawa fenol dalam asap cair. Menurut Zuraida et al. (2011) menjelaskan bahwa fenol memiliki aktivitas antibakteri dengan cara menghambat pertumbuhan bakteri. Fenol dapat bereaksi dengan membran sel yang menyebabkan meningkatnya permeabilitas membran sel, inaktivasi enzim-enzim esensial dan perusakan atau inaktivasi fungsional material genetik.

\section{Karakteristik Organoleptik Tahu Putih}

Pengujian sensori dikenal juga dengan pengujian organoleptik sudah ada sejak manusia menggunakan inderanya untuk menilai kualitas dan keamanan suatu makanan dan minuman. Hasil analisis Friedman pengaruh kombinasi perlakuan terhadap variabel organoleptik produk 
enkapsulasi asap cair disajikan pada Tabel 5.

Tabel 5. Hasil analisis Friedman produk enkapsulasi asap cair sekam padi terhadap variabel organoleptik

\begin{tabular}{llc}
\hline No. & \multicolumn{1}{c}{$\begin{array}{c}\text { Variabel } \\
\text { Organoleptik }\end{array}$} & $\begin{array}{c}\text { Kombinasi } \\
\text { perlakuan }\end{array}$ \\
\cline { 3 - 3 } & \multicolumn{1}{c}{ LK } \\
\hline 1. & Warna & $*$ \\
2. & Kenampakan & $*$ \\
3. & Tekstur & $*$ \\
4. & Aroma khas tahu & $*$ \\
5. & Aroma asap & $*$ \\
6. & Cita rasa & $*$ \\
7. & Kesukaan & $*$ \\
\hline
\end{tabular}

Keterangan: LK = kombinasi perlakuan antara lama penyimpanan dengan konsentrasi produk enkapsulasi; $*=$ berpengaruh nyata; $\alpha=5 \%$

\section{Warna}

Hasil analisis Fridman menunjukan bahwa kombinasi perlakuan lama penyimpanan dan konsentrasi produk enkapsulasi (LK) berpengaruh nyata terhadap warna tahu putih yang dihasilkan. Berdasarkan Tabel 6 bahwa selama penyimpanan warna tahu putih mengalami perubahan disebabkan terjadinya peningkatan jumlah mikroorganisme, sehingga kadar air menjadi semakin meningkat dan mempercepat kerusakan produk. Menurut Gandi (2013), kerusakan bandeng presto yang diakibatkan oleh bakteri antara lain adalah kehilangan warna dan rupa seperti warna kusam, bau tengik dan busuk, rasa dan teksturnya berair dan lembek. Banyaknya produk enkapsulasi yang ditambahkan membuat tahu putih berubah warna menjadi kuning keputihan.

Menurut penelitian Jamilatun et al. (2016), warna insang sampel ikan yang direndam menggunakan asap cair akan berubah dari kemerahan menjadi coklat muda. Perubahan warna ini disebabkan karena adanya senyawa karbonil dan fenol dalam asap cair. Menurut Ernawati (2015), banyaknya konsentrasi asap maka komponen asap yang teresap pada produk juga semakin banyak sehingga warna pada produk semakin coklat.

\section{Kenampakan}

Hasil analisis Friedman menunjukan bahwa kombinasi perlakuan lama penyimpanan dan konsentrasi produk enkapsulasi (LK) berperngaruh nyata terhadap kenampakan tahu putih yang dihasilkan. Berdasarkan Tabel 6 kenampakan tahu putih mengalami perubahan dikarenakan semakin lama penyimapan protein pada tahu dimanfaatkan oleh bakteri proteolitik sebagai sumber zat gizinya. Menurut Ernawati (2012) menyatakan bahwa mikroorganisme memanfaatkan protein untuk melakukan proses metabolisme. Menurut Kok and Park (2007), terbentuknya lendir mengindikasikan bahwa produk tersebut sudah mengalami kemunduran mutu akibat aktivitas bakteri, sehingga sebaiknya sudah tidak dikonsumsi lagi.

\section{Tekstur}

Hasil analisis Friedman menunjukan bahwa kombinasi perlakuan lama penyimpanan dan konsentrasi produk enkapsulasi (LK) berperngaruh nyata terhadap tekstur tahu putih yang dihasilkan. Berdasarkan Tabel 6 bahwa selama penyimpanan tekstur tahu putih mengalami penurunan mutu. Hal ini dikarenakan aktivitas bakteri. Menurut Angela et al. (2015), aktivitas bakteri dan enzim mengakibatkan degradasi jaringan pengikat sehingga menyebabkan menurunnya nilai tekstur akibatnya tahu menjadi lunak. Tumbuhnya mikroba juga disebabkan karena banyaknya air yang terkandung pada tahu putih selama penyimpan. Menurut Martinez et al. (2011), kandungan air pada ikan sangat berpengaruh terhadap tekstur. 


\section{Aroma Khas Tahu}

Hasil analisis Friedman menunjukan bahwa perlakuan kombinasi lama penyimpanan dan konsentrasi produk enkapsulasi (LK) berperngaruh nyata terhadap aroma khas tahu pada tahu putih yang dihasilkan. Tabel 6 menunjukan terjadinya perubahan aroma tahu putih dikarenakan produk enkapsulasi yang ditambahkan karena mengandung senyawa fenol. Menurut Saloko et al. (2013), senyawa fenol memberi kontribusi nyata terhadap aroma produk yang diawetkan dengan pengasapan. Lamanya penyimpanan juga berpengaruh terhadap aroma khas tahu putih. Menurut Swastawati et al. (2012) melaporkan bahwa semakin lama penyimpanan maka penerimaan terhadap aroma ikan pari asap dari asap cair tongkol jagung dan sabut kelapa akan semakin menurun.

\section{Aroma Asap}

Hasil analisis Friedman menunjukan bahwa perlakuan kombinasi lama penyimpanan dan konsentrasi produk enkapsulasi (LK) berperngaruh nyata terhadap aroma asap tahu putih yang dihasilkan. Berdasarkan Tabel 6 bahwa aroma asap pada tahu putih masih tercium dikarenakan adanya senyawa fenol. Menurut Saloko et al. (2013), senyawa

Tabel 6. Respon panelis terhadap nilai organoleptik berbagai kombinasi perlakuan tahu putih

\begin{tabular}{|c|c|c|c|c|c|c|c|}
\hline \multirow{2}{*}{$\begin{array}{l}\text { Kombinasi } \\
\text { perlakuan }\end{array}$} & \multicolumn{7}{|c|}{ Nilai organoleptik } \\
\hline & Warna & Penampakan & Tekstur & $\begin{array}{c}\text { Aroma khas } \\
\text { tahu }\end{array}$ & $\begin{array}{c}\text { Aroma } \\
\text { asap }\end{array}$ & Cita rasa & Kesukaan \\
\hline L1K0 & $1.60 \mathrm{a}$ & $1.88 \mathrm{a}$ & $2.60 \mathrm{ab}$ & $2.32 \mathrm{ab}$ & $3.02 \mathrm{abc}$ & $2.50 \mathrm{a}$ & $2.48 \mathrm{a}$ \\
\hline L1K1 & $1.90 \mathrm{ab}$ & $2.14 \mathrm{a}$ & $2.32 \mathrm{a}$ & $2.18 \mathrm{a}$ & $2.82 \mathrm{ab}$ & $2.48 \mathrm{a}$ & $2.50 \mathrm{a}$ \\
\hline L1K2 & $2.14 \mathrm{ab}$ & $2.58 \mathrm{ab}$ & $2.40 \mathrm{a}$ & $2.98 \mathrm{abcd}$ & $2.58 \mathrm{a}$ & $2.74 \mathrm{ab}$ & $2.82 \mathrm{abc}$ \\
\hline L1K3 & $2.08 \mathrm{ab}$ & $2.36 \mathrm{ab}$ & $2.88 \mathrm{ab}$ & $2.94 \mathrm{abcd}$ & $3.24 \mathrm{abc}$ & $2.60 \mathrm{ab}$ & $2.58 \mathrm{a}$ \\
\hline L1K4 & $2.22 \mathrm{abc}$ & $2.42 \mathrm{ab}$ & $2.76 \mathrm{ab}$ & 3.30 abcde & $2.74 \mathrm{ab}$ & $2.94 \mathrm{~b}$ & $3.00 \mathrm{abcd}$ \\
\hline L2K0 & 2.94 bcdef & $3.00 \mathrm{abc}$ & $3.12 \mathrm{abc}$ & $2.90 \mathrm{abc}$ & $3.34 \mathrm{bc}$ & - & $2.76 \mathrm{ab}$ \\
\hline L2K1 & $3.22 \mathrm{defg}$ & $2.96 \mathrm{abc}$ & $2.62 \mathrm{ab}$ & 3.42 bcde & $2.92 \mathrm{abc}$ & - & $3.22 \mathrm{abcd}$ \\
\hline $\mathrm{L} 2 \mathrm{~K} 2$ & $2.62 \mathrm{abcd}$ & $2.98 \mathrm{abc}$ & $2.78 \mathrm{ab}$ & 3.36 abcde & $2.98 \mathrm{abc}$ & - & $3.18 \mathrm{abcd}$ \\
\hline L2K3 & 2.84 bcde & $3.30 \mathrm{bc}$ & $2.98 \mathrm{ab}$ & 4.04 efg & $3.02 \mathrm{abc}$ & - & $3.48 \mathrm{bcd}$ \\
\hline L2K4 & 2.88 bcde & $3.12 \mathrm{bc}$ & $2.90 \mathrm{ab}$ & $3.86 \mathrm{defg}$ & $2.90 \mathrm{abc}$ & - & $3.50 \mathrm{bcd}$ \\
\hline L3K0 & $3.64 \mathrm{efg}$ & $3.50 \mathrm{~cd}$ & 3.42 bcde & $3.56 \mathrm{cde}$ & $3.48 \mathrm{c}$ & - & $3.62 \mathrm{cdef}$ \\
\hline L3K1 & 3.64 efg & $3.28 \mathrm{bc}$ & $2.98 \mathrm{ab}$ & $3.72 \mathrm{cdef}$ & $2.76 \mathrm{ab}$ & - & $3.66 \mathrm{cde}$ \\
\hline L3K2 & $3.40 \mathrm{defg}$ & $3.52 \mathrm{~cd}$ & $3.28 \mathrm{bcd}$ & $3.76 \mathrm{cdef}$ & $2.84 \mathrm{abc}$ & - & $3.72 \mathrm{defg}$ \\
\hline L3K3 & $3.72 \mathrm{efg}$ & $3.68 \mathrm{cde}$ & 3.44 bcde & $4.08 \mathrm{efg}$ & $2.76 \mathrm{abc}$ & - & $3.80 \mathrm{defg}$ \\
\hline L3K4 & $3.20 \mathrm{cdefg}$ & 3.56 cde & $3.30 \mathrm{bcd}$ & $3.90 \mathrm{defg}$ & $2.60 \mathrm{ab}$ & - & $3.82 \mathrm{defg}$ \\
\hline L4K0 & $3.72 \mathrm{efg}$ & $4.54 \mathrm{de}$ & $4.42 \mathrm{e}$ & $4.76 \mathrm{~g}$ & $3.26 \mathrm{bc}$ & - & $4.72 \mathrm{~g}$ \\
\hline L4K1 & $4.08 \mathrm{~g}$ & $4.44 \mathrm{de}$ & $3.98 \mathrm{cde}$ & $4.72 \mathrm{~g}$ & $2.86 \mathrm{abc}$ & - & $4.62 \mathrm{fg}$ \\
\hline $\mathrm{L} 4 \mathrm{~K} 2$ & $3.98 \mathrm{fg}$ & $4.64 \mathrm{e}$ & $4.42 \mathrm{e}$ & $4.76 \mathrm{~g}$ & $2.98 \mathrm{abc}$ & - & $4.64 \mathrm{~g}$ \\
\hline L4K3 & $4.16 \mathrm{~g}$ & $4.48 \mathrm{de}$ & $4.16 \mathrm{cde}$ & $4.68 \mathrm{fg}$ & $2.92 \mathrm{abc}$ & - & $4.56 \mathrm{efg}$ \\
\hline L4K4 & $4.00 \mathrm{~g}$ & $4.64 \mathrm{e}$ & $4.30 \mathrm{de}$ & $4.72 \mathrm{~g}$ & $2.90 \mathrm{abc}$ & - & $4.62 \mathrm{~g}$ \\
\hline
\end{tabular}

Keterangan: L1= lama penyimpanan 0 hari; L2= lama penyimpana 2 hari; L3= lama penyimpanan 4 hari; L4= lama penyimpanan 6 hari; $\mathrm{K} 0=$ konsentrasi $0 \%$ (kontrol); $\mathrm{K} 1=$ konsentrasi $0,5 \%$; $\mathrm{K} 2=$ konsentrasi $1 \%$; K3= konsentrasi 1,5\%; K4= konsentrasi 2\%; Angka yang diikuti huruf yang sama menunjukkan tidak ada perbedaan nyata pada uji Friedman dengan taraf $\alpha=5$ 
fenol memberi kontribusi nyata terhadap aroma produk yang diawetkan dengan pengasapan. Menurut Pagoray (2005), zatzat yang mendominasi pembentukan aroma atau bau adalah komponen-komponen asap yang melekat pada produk. Hasil penelitian Nensih (2016), penilaian panelis menurun pada tahu asap cair tempurung kelapa dikarenakan aroma dan rasa asap cair yang sangat kuat juga tekstur yang sedikit lebih keras.

\section{Cita Rasa}

Hasil analisis Friedman menunjukan bahwa kombinasi perlakuan lama penyimpanan dan konsentrasi produk enkapsulasi (LK) berperngaruh nyata terhadap cita rasa tahu putih yang dihasilkan. Parameter cita rasa hanya dilakukan pada hari ke-0 untuk mengetahui penerimaan panelis terhadap tahu putih yang telah ditambah produk enkapsulasi. Tabel 6 menunjukan bahwa adanya perbedaan cita rasa tahu putih dikarenakan adanya produk enkapsulasi yang ditambahkan. Menurut Milly et al. (2008), karakteristik asap kayu timbul karena adanya senyawa fenol. Konsentrasi fenol dapat menimbulkan respon yang berbeda seperti rasa asap yang tajam pada konsentrasi tinggi.

Hasil penelitian Nensih (2016), penilaian panelis menurun pada tahu asap cair tempurung kelapa karena aroma dan rasa asap cair yang sangat kuat juga tekstur yang sedikit lebih keras. Menurut Karseno et al. (2002), berbagai komponen kimia asap cair dapat berperan sebagai antioksidan dan antimikroba serta memberikan efek warna dan citarasa khas asap pada produk pangan.

Kesukaan

Hasil analisis Friedman menunjukan bahwa perlakuan kombinasi lama penyimpanan dan konsentrasi produk enkapsulasi (LK) berperngaruh nyata terhadap kesukaan tahu putih yang dihasilkan. Tabel 6 menunjukan bahwa kesukaan tahu putih mengalami penurunan mutu dikarenakan semakin lamanya penyimpanan. Menurut Tatengkeng (2007), menurunya kesukaan pada produk asap selama penyimpanan disebabkan karena senyawa-senyawa asap seperti fenol yang ada pada produk mengalami penguapan. Perbedaan nilai kesukaan pada produk enkapsulasi tahu putih dengan tahu yang berada dipasaran disebabkan karena adanya kandungan fenol pada produk enkapsulasi tahu putih. Menurut Atmaja (2009), senyawa fenol merupakan konstituen mayor yang berperan dalam pembentukan flavor pada produk asapan disebabkan oleh adanya komponen fenol yang terabsorbsi pada permukaan produk.

\section{Perlakuan Terbaik}

Penentuan perlakuan terbaik didasarkan pada parameter kimia dan biologi. Berdasarkan hasil uji DMRT kimia dan biologi bahwa tanpa penambahan produk enkapsulasi (konsentrasi 0\%) memberikan hasil yang berbeda nyata dengan penambahan produk enkapsulasi pada konsentrasi $0,5 \% ; 1 \% ; 1,5 \%$ dan $2 \%$. Konsentrasi produk enkapsulasi 0,5\% sampai konsentrasi $2 \%$ yang digunakan pada tahu putih tidak ada perbedaan yang nyata, namun pada konsentrasi produk enkapsulasi $2 \% \quad$ (K4) mampu mempertahankan mutu tahu putih paling rendah dibandingkan konsentrasi penambahan produk enkapsulasi lainnya.

Penentuan perlakuan terbaik ditinjau pula pada daya terima panelis, sehingga didasarkan pada parameter organoleptik. Berdasarkan hasil uji Friedman konsentrasi produk enkapsulasi $1 \%$ menghasilkan mutu tahu putih yang masi layak secara organoleptik sampai penyimpanan hari ke 2 (L2K2). Hasil organoleptik L2K2 yaitu warna 2,62 (putih keabuan); kenampakan 2,98 (mendekati agak bersih); tekstur 2,78 (mendekati agak kenyal); aroma khas tahu 3,36 (agak khas tahu putih); aroma asap 2,98 (mendekati agak menyengat) dan kesukaan 3,18 (agak suka). Penyimpanan tahu putih lebih dari 2 
hari tidak disukai panelis dikarenakan warna tahu putih semakin berubah, kenampakan yang berlendir dan tidak adanya aroma khas tahu putih.

Konsentrasi produk enkapsulasi $1 \%$ pada tahu putih menghasilkan warna putih keabuan pada hari penyimpanan ke-2, namun berbeda nyata dengan tanpa penambahan enkapsulasi dikarenakan adanya senyawa fenol. Reaksi kimia antara senyawa karbonil dengan gugus amino protein menghasilkan warna produk kekuningan keemasan sampai coklat gelap. Menurut Moejiharto et al. (2000), warna coklat tersebut disebabkan senyawa karbonil, jenis karbonil yang terdapat dalam asap cair antara lain adalah vanillin dan syring-aldehyde.

Penambahan konsentrasi produk enkapsulasi $1,5 \%$ dan $2 \%$ pada hari ke-2 kurang disukai panelis dikarenakan banyaknya produk enkapsulasi yang ditambahkan. Penabahan ini mempengaruhi warna tahu putih dan aroma asap yang lebih menyengat yang membuat aroma khas tahu putih kurang tercium. Konsentrasi produk enkapsulasi $0,5 \%$ yang ditambahkan terlalu sedikit menyebabkan senyawa fenol yang berfungsi sebagai antibakteripun sedikit, sehingga tumbuhnya bakteri semakin cepat yang membuat warna yang dihasilkan kurang disukai karena menjadi putih kekuningan dan aroma khas tahu putih kurang tercium.

\section{KESIMPULAN}

Asap cair sekam padi memiliki total fenol sebesar 1.624,62 mg GAE/g dan memiliki aktivitas antibakteri terhadap bakteri Escherichia coli ATCC dan Staphylococcus aureus ATCC. Produk enkapsulasi asap cair sekam padi memiliki total fenol sebesar $3.125 \mathrm{mg}$ GAE/g dan memiliki aktivitas antibakteri terhadap bakteri Escherichia coli ATCC dan Staphylococcus aureus ATCC. Konsentrasi produk enkapsulasi mempengaruhi nilai kadar air, kadar protein dan total plate count (TPC) tahu putih selama penyimpanan. Konsentrasi produk enkapsulasi $2 \%$ menghasilkan perubahan yang paling rendah selama penyimpanan. Konsentrasi produk enkapsulasi $1 \%$ menghasilkan mutu tahu putih yang masih layak secara organoleptik sampai penyimpanan hari ke-2.

\section{UCAPAN TERIMA KASIH}

Ucapan terima kasih ditujukan kepada PT. Indofood Sukses Makmur Tbk yang telah mendukung secara finansial terlaksananya penelitian ini melalui Program Indofood Riset Nugraha Tahun 2018.

\section{DAFTAR PUSTAKA}

Amaliyah, S. D. 2014. "Efektifitas Pemberian Konsentrasi Asap Cair Tempurung Kelapa (Cocos nucifera) dan Lama Penyimpanan Terhadap Jumlah Total Bakteri, Kadar Protein dan Organoleptik Ikan Gurami (Ospronemus gourami)". Skripsi. Fakultas Sains dan Teknologi, UIN Maulana Malik Ibrahim, Malang.

Andayani, R., Wijana, S., dan Mulyadi, A., F. 2014. Analisis kelayakan teknis dan finansial pendirian unit pengolahan limbah tempurung kelapa (asap cair dan karbon aktif). Jurnal Industria, 3 (3): 119126.

Association of Official Analytical Chemis [AOAC] t. 2005. Official Methods of Analysis. Association of Official Analytical Chemists. Benjamin Franklin Station, Washington.

Angela, G. C., Mentang, F., dan Sanger, G. 2015. Kajian mutu ikan cakalang (katsuwonus pelamis 1.) asap dari tempat pengasapan desa girian atas yang dikemas vakum dan nonvakum selama penyimpanan dingin. Media Teknologi Hasil Perikanan, 3 (2): 29-40.

Atmaja, A. K. 2009. "Aplikasi Asap Cair Redestilasi pada Karakteristik Kamaboko Ikan Tongkol (Euthynus affinis) Ditinjau dari Tingkat Keawetan dan Kesukaan Konsumen”. Skripsi. Fakultas Pertanian, Universitas Sebelas Maret, Surakarta. 
Badan Pusat Statistik. 2019. Rata-Rata Konsumsi per Kapita Seminggu Beberapa Macam Bahan Makanan Penting, 20072018. (http://www.bps.go.id.) [Diakses 21 Desember 2019].

Cahyadi, W. 2008. Analisis dan Aspek Kesehatan Bahan Tambahan Pangan (Edisi Kedua). Bumi Aksara, Jakarta.

Caliskan, G., and Dirim, S., N. 2013. The effects of the different drying conditions and theamounts of maltodextrin addition during spray drying of sumac extract. Food and Bioproducts Processing, 91 (4): 539-548.

Ernawati. 2012. Efek antioksidan asap cair terhadap sifat fisiko kimia ikan gabus (Ophiocephalus striatus) asap selama penyimpanan. Jurnal Teknologi Pangan, 4 (1): 121-138.

Ernawati. 2015. Pengaruh perlakuan asap cair terhadap sifat sensoris dan mikrostruktur sosis asap ikan lele dumbo (Clarias gariepinus). Jurnal Kelautan, 8 (2): 52-53

Fardiaz, S. 1992. Mikrobiologi Pangan I. Gramedia Pustaka Utama, Jakarta.

Febriani, R. A. 2006. "Pengaruh Konsentrasi Larutan Asap Cair terhadap Mutu Belut (Monopterus albus) Asap yang Disimpan pada Suhu Kamar". Skripsi. Fakultas Perikanan dan Ilmu Kelautan, Institut Pertanian Bogor, Bogor.

Gandi, L. 2013. "Perbedaan Jumlah Bakteri pada Bandeng Presto Berdasarkan Kondisi Sanitasi Penjualan Bandeng Presto di Pasar Johar". Skripsi. Fakultas Kesehatan Masyarakat, Universitas Muhammadiyah Semarang, Semarang.

Ginayati, L., Faisal, M., dan Suhendrayatna. 2015. Pemanfaatan asap cair dari pirolisis cangkang kelapa sawit sebagai pengawet alami tahu. Jurnal Teknik Kimia, 4 (3): 7 12.

Goodman dan Gilman. 2003. Dasar Farmakologi Terapi. Instituts Teknologi Bandung, Bandung.
Himawati E. 2010. "Pengaruh Penambahan Asap Cair Tempurung Kelapa Destilasi dan Redestilasi terhadap Sifat Kimia, Mikrobiologi dan Sensoris Ikan Pindang Layang (Decapterus spp) Selama Penyimpanan". Skripsi. Fakultas Pertanian, Universitas Sebelas Maret, Surakarta.

Jamilatun, S., Salamah, S., Alihati, A., dan Suminar, W. 2016. "Pengaruh Perendaman Ikan Nila dengan Asap Cair (Liquid Smoke) terhadap Daya Simpan". Seminar Nasional dan Teknologi. Universitas Muhammadiyah Jakarta, Jakarta.

Karseno., Darmadji, P., dan Rahayu, K. 2002. Daya hambat asap cair kayu karet terhadap bakteri pengkontaminan lateks dan ribbed smoke sheet. Agritech, 2 (1): 10-15.

Kok, T. N., and Park, J.W. 2007. Extending the shelf life of set fish ball. Journal of Food Quality, 30 (1): 1-27.

Kurniasih, R. A., Darmadji, P., dan Pranoto, Y. 2016. Pemanfaatan asap cair terenkapsulasi maltodesktrin-kitosan sebagai pengawet ikan cakalang (Katsuwonus Pelamis). Jurnal Teknologi Hasil Pertanian, 9 (1): 1-7.

Martinez, O., Salmero, J., Guillen, M.D., and Casas C. 2007. Textural and physicochemical changes in salmon (Salmo salar) treated with commercial liquid smoke flavourings. Food Chemistry, 100 (2): 498-503.

Martinez, O., Salmero, J., Maria, D., and Casas, C. 2011. Characteristics of dry and brinesalted salmon later treated with liquid smoke flavouring. Agricultural and Food Science, 20 (3): 217-22

Maryam. 2015. Aplications of liquid smoke powder as flavor and food preservative (case study: sponge cake). International Journal on Advenced Science Engineering, 5 (2): 7982.

Meilgaard, M.C., Gail, V.C., and Thomas, C.B. 2007. Sensory Evaluation Techniques. CRC Press, Washington. 
Milly, P.J., Toledo, R.T., and J. Chen. 2008. Evaluation of Liquid Smoke Treated Ready-To-Eat (RTE) Meat Product for Control of Listeria innocua. J. Food. Sci., 73: $179-182$.

Moejiharto,. Chamidah, A., dan Tri, E. 2000. "Pengaruh lama Perendaman dan Penyimpanan Ikan Bandeng Asap dengan Larutan Asap Cair terhadap Nilai Aw, Tekstur, Organoleptik dan Mikrobiologi”. Skripsi. Universitas Brawijaya, Malang.

Ningtyas, R. 2010. "Uji Antioksidan, Antibakteri Ekstrak Air Daun Kecombrang (Etlingera elatior (Jack) R. M. Smith) sebagai Pengawet Alami Terhadap Escherichia coli dan Staphylococcus aureus". Skripsi. Fakultas Sains dan Teknologi Universitas Islam Negri Syarif Hidayatullah, Jakarta

Nensih, S. 2016. "Pengaruh Konsentrasi Asap Cair Tempurung Kelapa Grade I untuk Menentukan Umur Simpan Tahu Kacang Kedelai (Glycine Max)". Skripsi. Fakultas Teknik, Universitas Pasundan, Bandung.

Pagoray, M. 2005. "Pengaruh Konsentrasi dan Cara Pemberian Asap Cair terhadap Mutu Organoleptik Fillet Cakalang (Katsuwonus pelamis L.) Asap". Skripsi. Fakultas Perikanan dan Ilmu Kelautan, Universitas SamRatulangi, Manado.

Prabawati, S., Suyanti dan Setyabudi, D.A. 2008. "Teknologi Pascapanen dan Pengolahan Buah Pisang". Seminar Badan Litbang Pertanian. Balai Besar Penelitian dan Pengembangan Pascapanen Pertanian, Departemen Pertanian, Bogor.

Putra, D. 2010. Asap cair pengawet makanan. (http://asapcairpengawetmakanan.wordpr ess.com) [Diakses tanggal 24 Juni 2019].

Rasydta, P. 2013. "Penggunaan Asap Cair Tempurung Kelapa dalam Pengawetan Ikan Bandeng”. Skripsi. Fakultas Matematika dan Ilmu Pengetahuan, Universitas Negeri Semarang, Semarang.

Sakti, H., Lestari, S., dan Supriadi, A. 2016. Perubahan mutu ikan gabus (channa striata) asap selama penyimpanan. FishTech-Jurnal Teknologi Hasil Perikanan, 5 (1): 11-18.
Saloko, S., Darmadji, P., Setiaji, B., and Pranoto, Y. 2012. Structural analysis of spray-dried coconut shell liquid smoke powder. Jurnal Teknologi dan Industri Pangan, 23 (2): 173-178.

Saloko, S., Darmadji, P., Setiaji, B., dan Pranoto, Y., and Anal, A.K. 2013. Encapsulation of coconut shell liquid smoke in chitosan-maltodextrin based nanoparticles. International Food Research Journal, 20 (3) :1269- 1276.

Senter, S. D., Robertson, J.A., \& Meredith, F.I. 1989. Phenolic compound of the mesocarp of cresthaven peaches during storage and ripening. Journal of Food Science, 54 (5): 1259-126.

Setha, B. 2011. Pengaruh penggunaan asap cair terhadap kualitas fillet ikan cakalang asap. Jurnal Ilmu Pengetahuan dan Teknologi, 9 (1): 2837.

Soeparno. 2005. Ilmu dan Teknologi Daging Cetakan Keempat. Gadjah Mada University Press, Yogyakarta

Swastawati, F. 2008. Quality and safety of smoked catfish (aries talassinus) using paddy chaff and coconut shell liquid smoke. Journal of Coastal Development, 12 (1): 47-55.

Swastawati, F., Susanto, R, Cahyono, B., and Trilaksono, W. A. 2012. Sensory evaluation and chemical characteristics of smoked stingray (dasyatis blekeery) processed by using two different liquid smoke. International Journal of Bioscience, Biochemistry and Bioinformatics, 2 (3): 212-216.

Tatengkeng. 2007. "Pengaruh Lama Pengasapan dan Lama Penyimpanan Terhadap Mutu Ikan Layang (Decapterus sp) Asap Pinekuhe". Skripsi. Fakultas Perikanan dan Ilmu Kelautan, Universitas SamRatulangi, Manado.

Wang, Y., Lu, Z.X., and Bie, X.M. 2009. Study on microencapsulation of curcumin pigments by spray drying. European Food Research and Technology, 229 (3): 391396. 
Wibowo, H., Muhajir, K., Rusianto,T., dan Arbintarso, E. 2008. Koduktivitas termal papan partikel sekam padi. Jurnal Teknologi Technoscientia, 1 (1): 26-30.

Yuliarti, N. 2007. Awas Bahaya dibalik Lezatnya Makanan. Andi Yogyakarta, Yogyakarta.

Zuraida, I., Sukarno., and Budijanto, S. 2011. Antibacterial activity of coconut shell liquid smoke and its application on fish ball preservation. International Food Research Journal, 18: 405-410. 